\title{
Analysis on the Development path of Mice Industry Based on Supply-side Reform
}

\author{
Guo Haixia \\ School of Management, Harbin University of Commerce \\ Harbin, China
}

\author{
Di Jiayu* \\ School of Management, Harbin University of Commerce \\ Harbin, China
}

\begin{abstract}
In recent years, China's exhibition economy has developed rapidly, but in the process of development, there are some problems such as unbalanced supply structure, low supply quality, unbalanced supply and demand and so on. By using the method of literature analysis and system model construction, taking the supply-side reform as breakthrough point, the author finds out the influencing factors which affect the development of mice and exhibition industry, and then constructs the dynamic mechanism of mice industry growth centering on structural models such as exhibition growth mode, growth motive force and so on. Through the dynamic system analysis of exhibition and exhibition industry, we can adjust the supply structure of exhibition industry, improve the quality of supply products, realize accurate supply, meet the requirements of all sides, strengthen creative planning, create the brand effect of exhibition and exhibition hall, strengthen our own exhibition, ensure diversified operation of stadiums and gymnasiums, and strengthen of government guidance and establishment of professional trade associations. From the perspective of supply-side reform, the extant problems of mice and exhibition industry are solved to maximize the benefits of the exhibition industry and ensure the rapid development of the exhibition industry.
\end{abstract}

Keywords-Exhibition industry; Supply-side reform; Development paths; Dynamic system Analysis

\section{INTRODUCTION}

In the past, influenced by the extensive growth mode of heavy quantity and scale, the supply quality of exhibition and exhibition industry decreased, the service level was low, the supply and demand was unbalanced, the supply structure of exhibition industry was unreasonable, and the demand of the main body of the industry could not be satisfied. Lack of brand effect and creative design, lack of reasonable use of exhibition elements, the exhibition industry development norms and guidance is not perfect and so on. At present, the central government puts forward the "supply-side reform" and takes effective measures to expand the effective supply. Therefore, it is urgent for the exhibition industry to respond to the national supply-side structural reform policy, to analyze the supply-demand relationship among the main bodies of the exhibition industry, and to carry out supply-side reform in the exhibition industry in order to achieve the balance between the supply and demand among the main bodies. To maximize the economic benefits and social value of the exhibition industry.

\section{LITERATURE REVIEW}

Huang Xiaoya put forward that there are structural problems in exhibition venues as one of the main bodies of the exhibition industry in Chongqing from the perspective of supply-side reform [1]. Dai Liyan pointed out that the main factor that affects the growth of exhibition economy at present is the imbalance between supply and demand. The government should continue to promote structural reform on the supply side [2]. Fang Luping pointed out in the Perspective of supply-side reform that only scientific methods should be used to analyze and study the present situation of China exhibition industry, and to solve the problems existing in the present exhibition industry [3]. Fan Jing and Wang Wencong pointed out that there is a structural imbalance between the consumption demand and supply of exhibition culture. We should start from the supply side, start with the upgrading of industry and the promotion of service, and realize the "new supply" of exhibition industry [4]. Wang Yilun, Ma Qiu-ling and Zhao Jianchun pointed out that the economic effect of the demand-side driven by investment, consumption and exports is declining day by day. In view of the imbalance contradiction of current economic structure, it is necessary to carry out supply-side reform to solve the essential factor contradiction, exhibition theme, capital operation, exhibition facilities and exhibition information [5]. Xiao Yun put forward that the exhibition tourism has some problems, such as the shortage of product supply is prominent, and so on, in the course of the supply-side reform of mice tourism in Guiyang. Need to combine with supply-side reform and put forward reform countermeasures such as setting up common idea [6].

\section{ANALYSIS OF EXHIBITION INDUSTRY STRUCTURE}

This part combines the perspective of supply-side structural reform to find out the key factors that hinder the development of mice and exhibition industry and to establish a dynamic growth system. It is analyzed comprehensively from two aspects: supply-side and demand-side:

\section{A. Dynamic system Analysis of Exhibition Industry structure}

Only when the supply structure and demand structure of the exhibition industry are in harmony with each other, can the structure of the exhibition industry be optimized and developed continuously. In the face of the market mechanism, there will be some deviation in the process of receiving the information of demand and supply, so it is necessary to analyze and intervene in the structure of the exhibition industry. In this 
paper, the impact of the exhibition industry structure is divided into two aspects: one is the demand side, the other is the supply-side effect, as shown in figure 1.

\section{1) Demand-side effects}

a) Trade: The transaction value is the most basic value obtained by exhibitors. For exhibitors, the main purpose of exhibitors is to trade with the audience and have the opportunity to reach a certain agreement for long-term trading. As a gathering platform, convention and exhibition can bring a large amount of passengers to meet the trade demand of exhibitors.

b) The whole city marketing: For the government and other industry associations, the exhibition industry marketing can be combined with the overall city marketing, through the establishment of the city iconic exhibition activities to promote the city image. Thus to promote the development of urban economy, but also through the overall marketing of the city to promote the coordinated development of the exhibition industry.

c) Integrated marketing: Exhibition industry is a platform to provide information, integrated marketing is the most effective means of exhibition industry. As a special form of marketing medium, the exhibition can combine marketing and sales. And most enterprises regard exhibitors as the means of integrated marketing strategy.

d) Publicity: An exhibition activity can provide an effective publicity platform for exhibitors. When the exhibition activities are propagated through various media, they will also play a joint and several publicity role to the exhibitors brands. Through the exhibition publicity, a large number of visitors to the exhibition brand image and product sales will play a great role.

e) Visits: For the general audience, the purpose of the exhibition is to visit, but will also produce a small number of transactions. The more close the theme to life, the more ordinary audience; the more professional theme, the more professional audience. Whether ordinary audience or professional audience, the need to visit is its basic purpose to participate in the exhibition activities.

f) Cooperation: Exhibitors and visitors to the exhibition, in addition to the general demand for trading, but also need to seek understanding of industry information, but also hope to work with other enterprise exhibitors, industry associations and even the government to reach a certain cooperation. At the same time, exhibitors can also invite some customers to the exhibition site to discuss cooperation to improve the effectiveness of the exhibition.

\section{2) Supply-side effects}

a) Services: the service system provided by the exhibition industry is not only the services provided by exhibitors, but also the services provided by the related industries which can be driven by the exhibition industry. The service of exhibition and exhibition usually shows three key points: facility service of exhibition hall, personnel service and commercial supporting service. The quality of the exhibition service directly affects the exhibitors and audience choice of the exhibition.

b) Information: Exhibition is a platform for information exchange and integration. Exhibition information includes industry information, enterprise information, product information, transaction information and so on. The greater the value of information, and the greater the attraction to exhibitors and professional audiences. Therefore, the exhibition activities should consider the quality and efficiency of information supply and enhance the information value of exhibition activities.

c)Products: The trading of products is the most basic supply of the exhibition. The most important purpose of the exhibitors is to promote and sell their own products, and the audience comes to understand and purchase the products. Therefore, providing attractive products is the main means of attracting visitors to the exhibition.

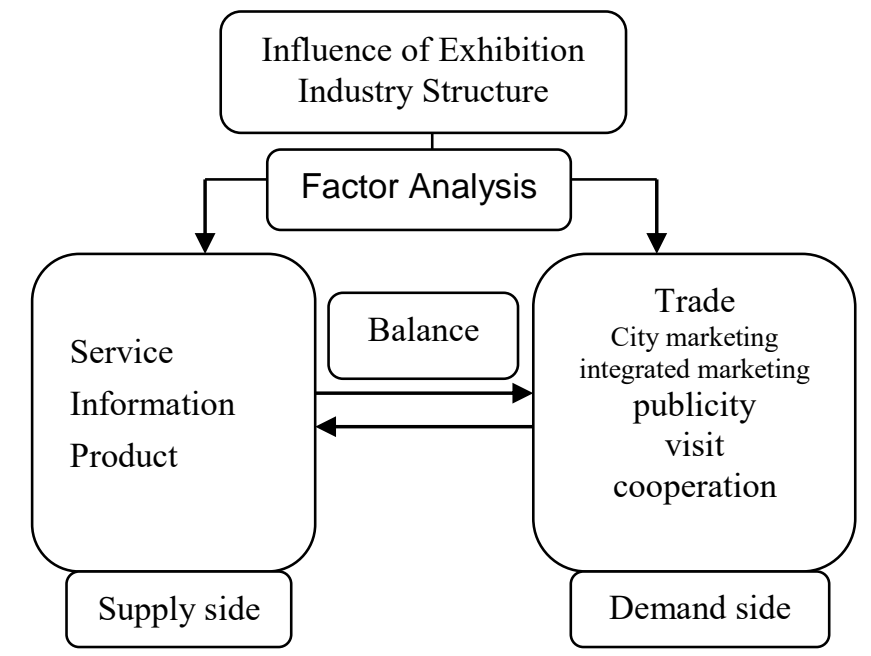

Fig. 1 The power system of exhibition industry structure of the theory of supply and demand balance

\section{B. Analysis on dynamic system of exhibition Industry growth}

When constructing the dynamic system of conference and exhibition industry structure under the background of supply-side reform, this paper studies the supply subsystem and demand subsystem from the point of view of affecting the development of the whole power system. The two subsystems are analyzed from two levels, which are the growth mode of exhibition industry and the motive force of exhibition industry growth, as shown in figure 2. The specific analysis of these two dimensions is as follows:

\section{1) Exhibition growth pattern structure}

In this aspect, the supply-side changes from low-cost elements to "three major engines", which include institutional reform, structural optimization and factor upgrading. In this part, exhibition industry should be reformed and innovated, and the government should provide some preferential policies to support the development of the exhibition industry and increase the total factor productivity. By adjusting the structure of exhibition industry, exhibition products and regional industrial environment can be allocated optimally and the balance between supply and demand can be realized. The 
process motive force is the factor upgrade, through optimizing the population and other factors of production to achieve, thus promoting the in-depth development of the economy, and in the exhibition industry, we also need to improve the quality of employees. Improve facilities and equipment. In this way, the "three major engines" become the driving force on the supply side and the "troika" the pulling power on the demand side. These two forces work together and contribute to the healthy development of the economy.

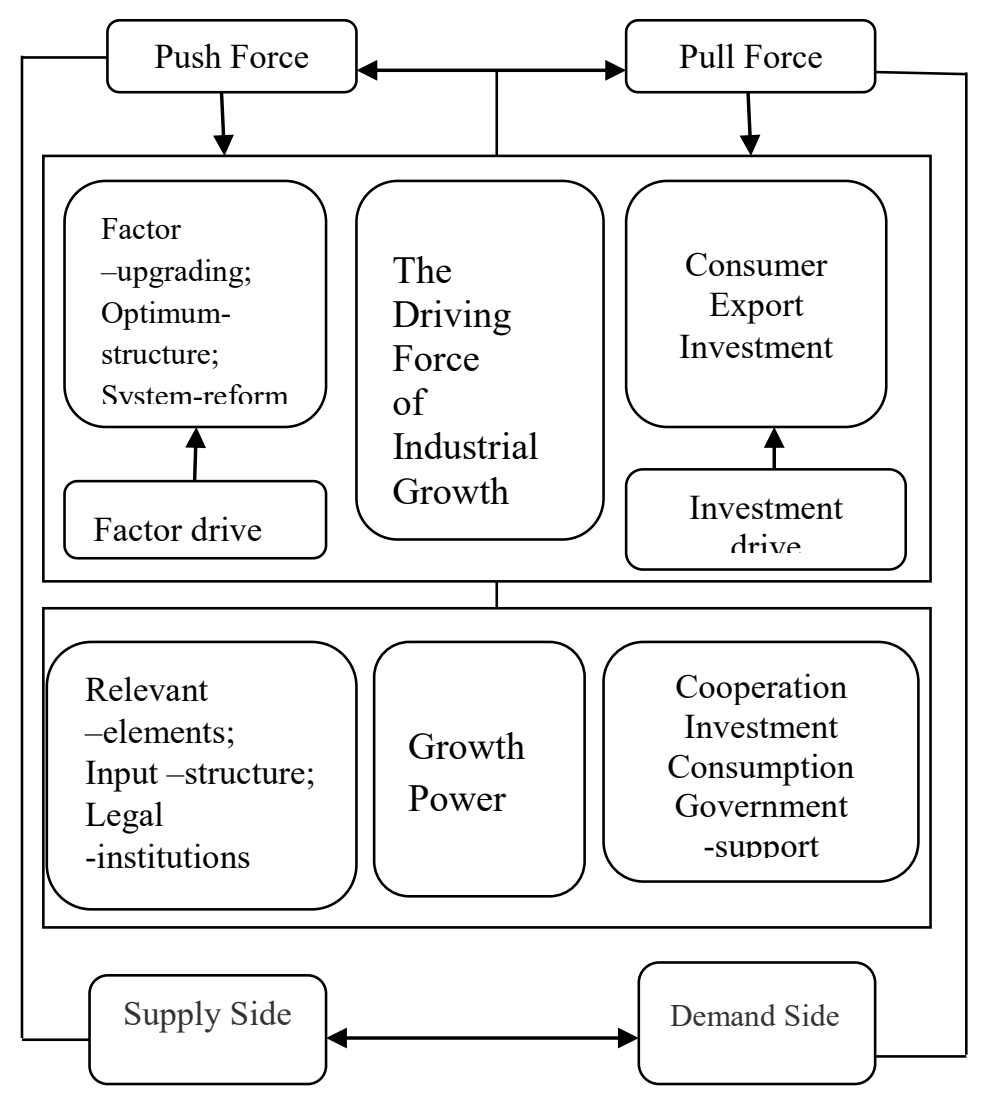

Fig. 2 Dynamic system of structure growth of Exhibition Industry

\section{2) Dynamic structure of mice and exhibition growth}

This level mainly includes two aspects: one is the supply-side dynamic growth, the other is the demand-side dynamic growth:

On the supply-side, the "three major engines" aim at the three aspects of factor upgrading, structural optimization and institutional change. The exhibition industry should optimize the relevant elements of the exhibition industry; Upgrading and optimizing the input structure of all bodies in the exhibition industry, adjusting the structure of the exhibition industry and the exhibition products, so as to optimize the allocation of resources; In addition, it is necessary to introduce the legal system of exhibition and exhibition, to strengthen the supervision of the exhibition industry, and to give some preferential policies to the exhibition activities at the same time.

On the demand side, the "troika" aims at consumption, export and investment. The exhibition industry should strengthen propaganda and media application, promote the consumption activities in the exhibition, and realize the transaction value. Cooperation with domestic and foreign exhibition subjects, in the process of organizing exhibitions, foreign exhibitors should be invited to promote transnational cooperation, but also with foreign exhibition companies to jointly organize international exhibitions; In order to attract all kinds of exhibition investment, the group exhibitors should attract many enterprises to invest in the process of raising funds and promoting the exhibition, and set up different investment schemes with different levels and different contents for them.

\section{THE ANALYSIS OF EXISTING CONTRADICTIONS AND PROBLEMS}

\section{A. Unreasonable supply structure of Exhibition Industry}

At present, the supply of products, services and information in China exhibition industry is an extensive and low quality supply. Some exhibition exhibits do not conform to the theme and the quality is not qualified, reducing the audience confidence in the exhibition; Some exhibition service level is not high, the service efficiency is low, reduced the audience satisfaction to the exhibition.

\section{B. The demand of the main body is difficult to satisfy}

At the present, some convention and exhibition organizers do not study the needs of the participants, but only provide the products, information and services they can provide to the participants. Such supplies are basically standardized and formalized. The individualized needs of participants in the exhibition activities are ignored and not satisfied, which leads to the difficulty of meeting the needs of the participants in the activities in an all-round way, thus reducing their enthusiasm for participating in the exhibition.

\section{Imbalance between supply and demand of each main body in exhibition industry}

In the exhibition industry, the exhibitors in order to pursue their own interests, do not respect the needs of market consumption, do not consider the needs of the audience, so the theme of the exhibition and market disconnect, not enough to attract exhibitors and audience participation. Although the number of exhibitions has increased sharply, there is no good guarantee in terms of quality. The theme repetition rate of the exhibition is high, industry information is closed, and the number of professional spectators participating in the exhibition is low, which results in poor performance of exhibitors participating in the exhibition. However, most of the exhibition venues are not conducive to the overall marketing of the city as a symbol of the government. The supply and demand of each main body of the exhibition industry is staggered

\section{Lack of brand effect and innovation supply}

At the present, the number of exhibitions in our country has increased sharply and the scale has been constantly expanding. At the same time, due to the lack of control by trade associations and venues, the theme repetition rate of the exhibition is high. Disperse the influence of leading trade fair, resulting in exhibitors cannot guarantee the effect of exhibitors. Moreover, group exhibitors pay more attention to short-term 
income, lack of brand marketing strategy and no brand effect. It can be seen that the exhibition industry is in urgent need of reform, strengthening the exhibition brand effect and innovation drive, so that supply and demand tend to balance.

\section{E. Imperfect norms and guidance for the Development of Exhibition Industry}

The development of exhibition industry needs the standard and guidance of government and trade association to ensure the healthy and balanced development of exhibition industry. Although some local governments and trade associations have issued a series of policies to promote the healthy development of the exhibition industry, the implementation of the policy is not strong and the effect is not obvious. And the lack of laws and regulations on industry norms, leading to some infringement of intellectual property rights, deception, fraud phenomenon repeatedly prohibited.

\section{SUGGESTIONS FOR OPTIMIZING AND UPGRADING THE EXHIBITION INDUSTRY}

\section{A. Improving the supply quality by adjusting the supply} structure of Exhibition Industry

In order to promote the sustainable development of the whole exhibition industry, it is necessary to adjust the supply structure of the exhibition industry. According to the business license of the exhibitors, the exhibitors shall supervise the exhibitors to ensure that they are relevant to the theme of the exhibition. The information provided by the exhibition activities should be able to represent the development trend of the industry. The latest information of exhibition customers is timely and accurately transmitted to the information recipients to ensure the efficiency and benefit of the exhibition information in the exhibition activities.

\section{B. Using Precision supply to meet the demand of all bodies}

Accurate supply is to provide the corresponding supply according to the demand of each main body. The premise of accurate supply is to know what the demand side is. One way is to forecast the possible demand of most exhibitors and audience according to the previous exhibitors and the other is to distribute the demand questionnaire according to which the exhibitors and the audience need to be counted. According to the survey and analysis of exhibitors and audience demand situation, and then provide the corresponding supply.

\section{Pay attention to the demand of each subject and pursue the balance of supply and demand}

The imbalance between supply and demand of exhibition industry is serious, which is the key problem affecting the development of exhibition industry. In order to solve this problem, first of all, we need to pay attention to the market demand, adjust the supply according to the demand. Provide accurate supply, improve the efficiency and effect of the exhibition industry, reduce the waste of resources. Secondly, all bodies should strengthen communication and cooperation. Group exhibitors need to fully consider the needs of exhibitors, professional audience, do not blindly follow other exhibitions. Exhibitors should also fully understand the needs of the audience, and to provide services to meet their needs, to achieve a balance between supply and demand.

\section{Promoting the Brand effect and Innovation ability of Exhibition activities}

However, due to the lack of standardized management and lack of innovation, it is difficult to form brand effect. In this case, first of all, exhibitors should attach importance to creative planning in exhibition theme and process services, and form their own unique characteristics. Secondly, group exhibitors can plan corresponding activities, such as conferences, etc. This is even more conducive to the participation of ordinary audiences to enhance the visibility of the exhibition. In order to achieve the balance of supply and demand, the exhibition activities should improve innovation ability and brand effect in a variety of ways.

\section{E. Strengthening the guidance of the government and trade associations}

In order to ensure the efficient and healthy development of the exhibition industry, the government must strengthen guidance and establish professional trade associations to support it. The government and trade association should introduce laws and regulations to promote the development of exhibition industry and strengthen the law enforcement to standardize the healthy development of the industry and protect the rights of all parties. In addition, the government should provide certain preferential policies to the exhibition to promote regional economic development. The government should also make the exhibition a part of the city business card to promote the development of the exhibition and enhance its popularity.

\section{CONCLUSION}

As a new economic growth point, exhibition industry not only plays a more and more important role in economic development, but also plays a linkage role to the whole society and the market. It can promote the development of related industries and employment. As a business card of a city, it can promote the overall marketing of a city, raise its popularity, and affect the economic development of a city. This paper clarifies the factors of supply and demand in the structure of exhibition industry, finds out the problems existing in the structure of exhibition industry, and to achieve the balance between supply and demand among the main body. To make exhibition industry create more economic value and social value.

\section{REFERENCES}

[1] Huang Xiaoya. A study on the Development of Chongqing Convention and Exhibition venues from the Perspective of supply-side Reform,2017.

[2] Dai Liyan. A study on driving Exhibition and Industry Development from the Perspective of supply-side Reform,2018.

[3] Fang Luping. A study on the Development Strategy of mice Industry from the Perspective of supply-side Reform,2016.

[4] Fan Jing, Wang Wencon.Study on the path of supply-side reform of exhibition culture industry; 2017.

[5] Wang YR, Ma QL, Zhao J C.Study on supply-side reform and agglomeration diffusion effect of exhibition industry; 2017.

[6] Xiao Yun. "A brief Analysis of the path of supply side Reform of mice Tourism in Guiyang City", 2017. 